\title{
THE ESSENCE AND SOURCES OF OPPORTUNISM IN BUSINESS ACTIVITY
}

As observed in recent years, the increased interest in the problem of opportunism in business activity is mainly attributable to the new institutional economics, according to which limiting this phenomenon has become the basic means of reducing transaction costs, and consequently also improving efficiency. The relations between opportunism and transaction costs are discussed in this study, which also addresses the very essence of opportunism, but the author's attention was mainly focused on the sources of opportunism. The most important ones, namely specific assets and turbulent environment, were analysed in detail. The purpose of the article was to determine how and to what extent these sources contribute to the opportunistic behaviour displayed by parties to a transaction. The author also described the relations between specific assets and a turbulent environment.

Keywords: opportunism, specific assets, turbulent environment, transaction costs JEL Classification: D82, G34, L14

DOI: $10.15611 /$ aoe.2021.2.01

\section{INTRODUCTION}

The interest in opportunism in business activity is associated with the increasing popularity of the transaction cost theory which is currently one of the dominant theories in management science (Verbeke, Greidanus, 2009: 1471). Its popularity has rapidly grown since the 1975 publication of Markets and Hierarchies by O. E. Williamson, according to whom, opportunism is the centre piece in the analysis of transaction costs (Williamson, 1975, 2008). A decided majority of other authors share this opinion (Grover, Malhotra, 2003: 457-473), while Wilkin claims that transaction costs are the "consequence of uncertainty as to the integrity of counterparties" (Wilkin, 2016: 158). This leads to contractual provisions being extended in such a manner as to protect the parties to the contract against the consequences of the counterparty's unfair conduct, which causes transaction costs to rise.

There is nothing in the papers by Williamson to imply that each stakeholder behaves in an opportunist manner, however he claims that there is the threat of

\footnotetext{
* Department of Management, WSB University in Gdansk, Poland.
} 
opportunist attitudes ultimately surfacing, which may even apply to the majority of stakeholders, thus opportunism is an important cause of unequal motivation as well as of conflicts and disputes. In his opinion, potential or actual opportunism exerts a fundamental impact on the choice of management structure, adding that lack of opportunism may lead to the elimination of any kind of advantages in management systems. In the absence of opportunism, businesses and markets should attain equal economic benefits.

Perceiving opportunism as an aspect of the key role is a view which numerous authors consider rather controversial. This group includes G. M. Hodgson, who believes that there is a number of other reasons why transaction costs are generated (Hodgson, 2004: 401-418), and claims that conflicts or disputes may arise even in the absence of opportunism (although this takes place on different grounds), that the commitment of individual persons in the work they perform may be associated with their personal traits, and that businesses incur the risk of their ill-judged decisions, etc. According to the latter, Williamson's position on opportunism being central to the analysis of transaction costs is erroneous not because opportunism does not happen in the real world, but because there are also other important reasons behind contracting issues. Treating opportunism as the only source of transaction costs leads not only to the incomplete identification of problems in the management structure, but can also be the cause of the mistakes made when designing institutions or applying managerial practices. Hence, his general conclusion is that opportunism does not constitute the sole reason behind the differences in management structures.

The purpose of this study was to establish the essence as well as the sources of opportunism in business activity. An attempt was made to test the hypothesis on the fundamental impact of specific assets and turbulent environment on the display of opportunist attitudes by parties to a transaction. In this verification attempt, the author focused on analysing the factors which comprise the aforementioned sources of opportunism, and applied the method of critical analysis of the literature - both Polish and international.

\section{ESSENCE OF OPPORTUNISM}

It is to new institutional economics (NIE) that one can attribute the growing interest in opportunism in business. ${ }^{1}$ According to this concept, controlling this phenomenon is considered to be the main means of increasing the

\footnotetext{
${ }^{1}$ The interest in opportunism was also among the aspects considered in the earlier concept of behavioural economics, although to a lesser extent. The same theme can also be found in experimental economics.
} 
efficiency of economic entities (Noorderhaven, 1996: 105-123). Contrary to neoclassical economics, under NIE, individuals are not perceived just as they are. This concept discerns their aims, predilections and views. It also recognises their opportunist attitudes or behaviour patterns, especially those that can be observed in businesses. Their propensity for opportunism is the reason why the latter should be taken into consideration when both concluding and performing contracts.

Opportunism is a subtle and deeply ingrained feature of human nature, and as such, it should be addressed in studies of economic organisations. Williamson claims that opportunism should be understood as "self-interest seeking with guile, (...) which pertains to either the incomplete or distorted disclosure of information, and particularly to intentional efforts aimed to misguide others, distort, conceal, obscure or tangle matters in some other way (Williamson, 1998: 60). Some authors understand opportunism in a similar manner. Jap et al. perceive opportunism as the efforts undertaken to achieve benefits by violating the rules of ethics at the expense of other market participants (Jap et al., 2013: 216-227). According to Ganesan et al., one is dealing with opportunism when the parties to the contract fail to perform the obligations they have assumed, exploit the loopholes in the contracts they have concluded, demand concessions to which they are not entitled, and for these purposes they make use of their market position (Ganesan et al., 2010: 361-373).

Polish authors tend to have a slightly different opinion on opportunism. For instance, Piórkowska calls it "an attitude characterised by abandoning moral rules or ideological beliefs in the pursuit of short-term benefits in life; always choosing what is secure and beneficial in the given situation; love of comfort in life" (Piórkowska, 2013: 338). For Wilkin, "the notion of opportunism (...) means acting without abiding by the rules, seizing all opportunities for one's own benefits, love of comfort, etc." (Wilkin, 2016: 159). Therefore, one should rather agree with Lissowska, claiming that the meaning of the word opportunism differs to a certain degree in Polish and in English. In Polish, it means a tendency to compromise and a comfort-prone nature, which makes its interpretation significantly milder compared to English, where it is associated with deceit, deception, lie, etc. (Lissowska, 2008: 61). What may also be added in this respect is that most Polish authors adopt Williamson's definition, as provided above, to function as the foundation of their analyses (Marcinkowska, 2017: 223).

In searching for the original source of opportunism in businesses, one should examine the phenomenon of ownership separation from management. It was precisely in this process that individual corporate bodies emerged, with 
professional managers usually holding an established position of authority. This authority was typically based on appropriate professional competence, on the one hand, while on the other hand, on extensive access to information. Both these premise are extremely important for business operations, and due to the growing complexity of management processes, both have strengthened the position of managers inside businesses at the expense of the authority of owners, especially those who hold rather insignificant blocks of shares. At the same time, managers also started complaining about the authority of dominant shareholders, which they perceived as restrictive towards their own actions, comparing it to a corset constraining their decision-making capacity. The owners' interest, which generally came down to maximisation of the market value of the capital they had invested, was often in contradiction to that of managers, which manifested itself in their high wages, building their own position in the market, or even the ineffective expansion of the company structure.

Williamson claims that opportunism is the source of uncertainty when closing commercial transactions. This happens because the parties who show an inclination towards opportunist behaviour are not entirely trustworthy. Consequently, transactions exposed to displays of opportunism should be adequately protected before making a deal. Not until individual persons are recognised as open and reliable in their pursuit of individual benefit does the related uncertainty fade. One can also achieve such objectives by being completely subdued and obedient. The latter should be understood as abandoning the pursuit of one's own interest (Williamson, 1998: 61-62).

The aforementioned propensity for opportunist behaviour forces companies to actually take this phenomenon into account in their operations. This particularly applies to their growth strategies, in the development of which businesses should consider the possibility that the entities with which they collaborate behave in an opportunist fashion, understood as the broad range of customer behaviour patterns, their needs and expectations, as well as the conduct of suppliers, banks, public administration bodies, local authorities, etc. Therefore it is in the company's interest to take into account displays of opportunist behaviour, being considerably distant from rationality, in the aforementioned strategies. Rationality understood as acting in accordance with logic, involves the selection of the proper means needed to achieve the assumed aims that are coherent with the acquired knowledge and with the system of values.

However, the relations between rationality and opportunism are far more complex. When determining them according to NIE, one typically applies the model of an economic man (Homo economicus) by Jensen and Meckling, 
being an attempt to bind rationality with opportunism (Jensen, Meckling, 1994: 4-19). In this model, the economic man chooses a goal by taking the existing limitations into consideration. These limitations may pertain to the knowledge one has or the capacity to acquire information. This model admits opportunist behaviour if it leads to reaching specific pre-defined goals. Such behaviour is also justified when such a person, with all of their creativity and adaptiveness, can better adapt to the situation at hand. It is necessary to analyse the factors which condition opportunism in order to understand its complex nature and manage it effectively.

It should be noted that exploitation of opportunities for one's own interest does not always bear the hallmarks of opportunist behaviour. Not until an individual or a group compromises the interest of others, acts to their disadvantage, resorts to deceit, deception or lying in pursuit of their own interest, does one deal with opportunism. It may also be described as a departure from the spirit of collaboration (Williamson, 2005: 46). As mentioned, however, opportunism in practice is actually not that common. It is more an issue of insurance policies or managing public goods. ${ }^{2}$

Not until the 1970s was the interest in opportunism in the theory of economics observed to significantly increase. It was then that the first attempts to operationalise transaction costs were made. The research on the possibility to limit such costs, which can subsequently decide about efficiency of an organisation, has drawn scientists' attention to the important role of opportunism and its source. The literature on opportunism is quite extensive, however, it is mainly focused on the influence it exerts on transaction costs. In fact, there are not any publications solely devoted to various aspects of opportunism or publications presenting the results of relevant empirical research, where the latter ones are very scarce indeed. The analysis of these articles allowed the author to identify the main sources of opportunism such as specific human assets and turbulent environment. The relations between transaction costs, opportunism and specific assets, turbulent environment are shown in Figure 1.

\footnotetext{
${ }^{2}$ In the literature, there are various types related to the division of opportunism, which are based on some specific criteria. Most frequently, authors assume stages of relations as the criteria for such a division and they define ex-ante opportunism and ex-post opportunism. Exante opportunism can be observed when opportunistic activities appear during the initial stages of relations, whereas ex-post opportunism shows when opportunistic activities appear during the final stages of relations (Williamson 1998: 60). Another type of division refers to the criterion of activity, based on which active opportunism and passive opportunism can be distinguished (Wathne, Heide 2000: 36-51).
} 


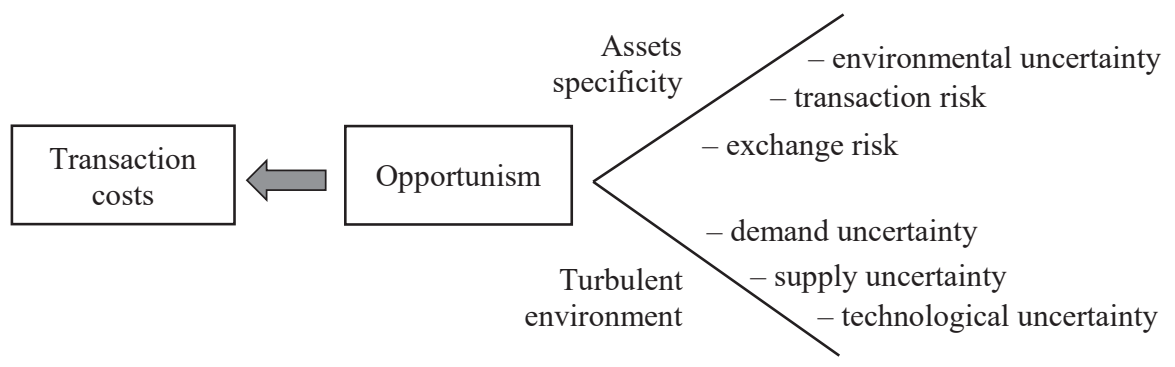

Fig. 1. Effect of assets specificity and turbulent environment on opportunism and transaction costs

Source: author's own study.

The relations between opportunism and transaction costs have been extensively discussed in the literature of the subject (Grover, Malhotra, 2003; Handley, Benton, 2012). As was already mentioned, the impact of opportunism on the level of transaction costs is commonly accepted, which does not mean that there are no other factors affecting these costs, one of them is the repeatability of transactions (Williamson, 1979: 233-261), whilst numerous authors make reference to other sources of opportunism. ${ }^{3}$

The sources of opportunism, such as specific assets and turbulent environment, are the objects of further elaborations provided in this paper. Each of these sources comprises numerous factors which may induce opportunistic behaviour to a greater or lesser extent.

\section{SPECIFIC ASSETS AS THE SOURCE OF OPPORTUNISM}

It is mostly for the specificity of assets that the economics of transaction costs stands out distinctively from the other approaches to the analysis of business entities. Parties to a transaction can usually choose between special purpose and general purpose investments. The former typically entail significant cost reduction, however one must bear in mind that they are, by definition, risky investments, since the specific assets generated in such a manner cannot be moved, if necessary, without their productivity being reduced. An example of such a case may be contract termination or alteration

\footnotetext{
${ }^{3}$ Among them, they also consider the limited, or absence of information. Under certain circumstances, both having and not having important information may trigger opportunist attitudes in partners (Chakravarti, 2017: 1114-1136). Strong competition is also mentioned as a source of opportunism. The continuous struggle for efficiency increase encourages opportunistic behaviour (Hawkins et al., 2008: 905).
} 
of the production profile, limiting the capacity to utilise such assets. Therefore, one must first consider if the expected cost reduction related to such investments actually substantiates the risk being incurred as well as the resultant threats.

General purpose investments typically generate no such problems. The assets produced by that means may be widely used for the sake of other investments, and if necessary they can be easily moved. The mobility of such assets is an important advantage, which employers particularly appreciate. They can be transferred with minimum or even no loss.

An employee with qualifications which the given company considers unique cannot leave without any loss, since he/she will not find another job which makes the most of the qualifications at hand. This may mean that such an employee will rarely display opportunist behaviour, while more often is expected to show full commitment and integration with the company. It is obviously also possible that an employee with unique qualifications should threaten the employer to leave if the latter fails to meet their excessive demands, for instance in terms of remuneration. However, this is a fairly rare situation, and it is precisely due to the aforementioned damage that the employee suffers when changing workplace. Therefore, it may be generally concluded that the predominant factor affecting the opportunist behaviour is dependence, while the key factor to being dependent is the specific assets (Huo et al., 2018: 155).

It should be noted that the specificity of assets is a very extensive category, comprising many of their types. Williamson mentions four types of asset specificity: site specificity, physical specificity, human asset specificity, and dedicated asset specificity [Williamson, 1998: 68]. Specific assets can be either of a material nature (plant, equipment, location, etc.) and non-material nature (software, personnel, knowledge). Each of those entails different specific organisational consequences, therefore they are best analysed against the context of specific organisational problems (vertical integration, nonstandard contracting, employment, corporate management, etc.).

Specific assets constitute the source of transaction risk and exchange risk (Handley, Beenton, 2012: 55-68). The transaction cost theory is based on the assumption that specific assets intensify the opportunism which results from increased transaction risk. A party investing in specific assets is doomed to defeat if its non-investing partner is capable of obtaining a quasi-rent on the specific assets, e.g. as a result of ex-post negotiations, or by threatening to terminate the contract. Moreover, investing in specific assets is subject to codification and knowledge transfer (Clemons et al., 1993). The investing party may suffer damage by losing control of their own assets if the counterparty attains benefits on the disclosed information and expertise. 
The research performed in this area implies that investments in specific assets may cause different levels of opportunism to emerge (Huo et al., 2018: 154-156). If the party investing in specific assets is a manufacturer, or the supplier of raw materials or semi-finished products, they may exploit their bargaining position by disclosing confidential information or withholding information concerning the quality of supplies, costs, performance, etc., which are manifestations of opportunist behaviour. One may expect of a supplier investing in specific assets to abstain from opportunist practices, which is understandable since, making such investments, the supplier is exposed to a higher risk of loss in the event that their collaboration with the manufacturer is terminated. Under such circumstances, their dependence on the manufacturer increases, which typically strengthens their commitment and restricts opportunist conduct.

There are numerous studies addressing this problem, including the survey conducted in 212 small and medium-size enterprises in Norway (Mysen et al., 2011: 436-449). With reference to this research, one can conclude that manufacturers' investments in specific assets which bring benefits to suppliers increase the former's dependence on the latter, as a result of the manufacturer's reduced flexibility. This means that the suppliers can exploit this dependence through opportunist behaviour. At the same time, if the supplier has adapted most of their operations to the manufacturer's requirements, and has invested in specific assets for the sake of the manufacturer's needs, the supplier will bear considerable costs if they should cease to collaborate. These costs make the supplier dependent on the manufacturer, which may tempt the latter to resort to opportunist conduct and exploit their relationship, for instance by evading their obligations.

In conclusion of this section of the study, it should be noted that investing in specific assets is an important source of opportunism, which consequently leads to an increase in transaction costs. Bearing that in mind, it is be reasonable to ask whether or not such investments are economically sound. Section 5 provides an answer to this question.

\section{THE IMPACT OF TURBULENT ENVIRONMENT ON OPPORTUNIST ATTITUDES}

Turbulent environment is understood as the entirety of unforeseen changes in transaction conditions (Noordewier et al., 1990), where it exerts a significant impact on the uncertainty of the environment in which the transaction is performed, being the direct cause of limited rationality. On account of the growing uncertainty, such an environment reduces the planning capabilities 
and makes the behaviour of the transaction counterparties difficult to predict, and this uncertainty often leads to contracts being renegotiated or interpreted in an opportunist manner. It should be noted that the uncertainty of an environment depends to a considerable extent on external factors, which the parties do not control. This does not concern the specific assets, analysed above, which are internal factors, and as such depend on the decisions made by the counterparties.

The main cause underlying turbulent environment is growing competition, causing the parties to the transaction to behave aggressively, which typically leads to price-based competition. Under the conditions of such competition, businesses must continuously monitor the changes taking place in the market and respond to them accordingly by adapting their products to the changing preferences, requirements and needs of customers. Therefore, one can formulate a general conclusion that intense competition is evidence of turbulent environment.

The relations between turbulent environment and opportunism have not been explicitly confirmed, mainly due to the limited scope of research pertaining to this problem (Carson et al., 2006). However, it is accepted that under the conditions of turbulent environment the threat of opportunist practices grows, both when concluding and when performing transactions. Numerous authors confirmed this relation to be true (Schelling, Steensma, 2002; Wang et al., 2013). Referring to the transaction cost theory, one can conclude that turbulent environment causes problems with the adaptation and evaluation of the current situation, thus increasing overall transaction costs due to the growing costs of both coordination and transaction risk. Turbulent environment may invalidate the contract previously concluded because some of its provisions may have changed. This forces the parties to communicate and make arrangements more frequently, and even to renegotiate their contract in order to adapt it to the variable conditions. The consequences of such actions are growing coordination costs and declining mark-ups of suppliers. At the same time, this uncertainty hinders the monitoring, assessment and control of suppliers, which translates into the increased risk of opportunist practices.

What the researchers tried to establish in the aforementioned surveys was which of the three dimensions of turbulent environment mentioned in Figure 1 , namely uncertainty of demand, uncertainty of supply, and uncertainty of technology, triggers opportunist behaviour (Bhattacharya et al., 2015; Handley, Benton, 2012). Uncertainty of demand causes the scope of demand changes to grow and makes it unpredictable. This forces the parties to exchange information more frequently as well as to perform ongoing coordination. 
Consequently, suppliers are additionally encumbered in relation to the need for identifying and responding to consumer needs on an ongoing basis. Uncertainty of demand makes it difficult for suppliers to determine the relevant requirements on an ex-ante basis, making contractual provisions ambiguous. This situation encourages opportunist behaviour, which has been confirmed by the previous research, implying that uncertainty of demand is positively correlated with opportunism.

Uncertainty of supply entails high supply dynamics and unpredictability of prices of the goods and services delivered, and it may also reduce the capacity to deliver goods and services, cause their quality to fluctuate, etc. Uncertainty of supply makes it all the more difficult to arrive at precise contractual arrangements, stipulating company expectations and suppliers' obligations. Suppliers may exploit the loopholes in contracts for the sake of their competitive advantage. From the company perspective, uncertainty of supply also hinders monitoring and the assessment whether suppliers comply with the relevant contractual provisions. Businesses are incapable of predicting the extent to which their expectations will be met, and neither can they make an informed judgement about the quality of the goods and services they receive from their suppliers. Consequently, the level of performance of the contracts concluded may decline. The research implies that there is a positive correlation between uncertainty of supply and opportunism.

The third kind of uncertainty concerns technology, and it pertains to the extent of changeability and unpredictability of technology. Technological progress is a significant aspect of competitiveness. In light of rapid technological changes, contractual provisions can become outdated. Where this is the case, uncertainty of technology leads to the invalidity of contracts and encourages opportunist behaviour. Moreover, the great uncertainty of technology makes the existing technologies obsolete very quickly, which also affects the capacity to fulfil one's obligations. Thus manufacturers may be exposed to the risk of opportunism of suppliers.

Huo et al. (2018: 158-161) suggested that this problem is more complex. They studied it in companies operating in the logistics sector by analysing 247 relations of the 3PL system. Their research demonstrated no explicit correlations between the uncertainty of technology and opportunism, however, no such correlations could be excluded. This confirmed the pre-defined hypothesis that uncertainty of supply increased the probability of opportunist attitudes. However, what the research did not support was the assumption of explicit correlations between uncertainty of demand and opportunism.

In order to explain these correlations, the author employed the resource dependence theory, according to which the given business's position depends 
on the resources in its possession, on which other businesses depend (Pfeffer, Salancik, 2003). Since production companies present the demand for services, e.g. in logistics, they have easier access to information concerning the demand for these services. Correspondingly, suppliers have access to more extensive information about the provision of logistic services. If the case of a low level of uncertainty of demand or supply, both manufacturers and suppliers can correctly estimate the magnitude of demand and adapt to it properly. However, in the event of a high level of uncertainty of demand or supply, the available information on this matter is limited, giving priority to companies in disposal of more accurate information. Under such conditions, a company having the information advantage could make the most of it for its own benefit.

At the same time, a company in an unfavourable position may be dependent on others that hold the relevant information, which is why the former would be interested in building long-term relationships and abstain from opportunist conduct. It is particularly under conditions of high uncertainty of demand that manufacturers have the information advantage, while suppliers experience a deficit in this respect. In such a situation, service providers display an inclination towards limiting their opportunism in favour of becoming more engaged, hoping to obtain access to the information they desire. Facing the high uncertainty of service supply, on the other hand, providers gain the upper hand in terms of the information concerning their services, and their competitive position improves. This gives rise to conditions favouring the pursuit of one's own opportunist interest.

\section{RELATIONS BETWEEN TURBULENT ENVIRONMENT AND SPECIFIC ASSETS}

Most of the research conducted to date has concentrated on the impact of turbulent environment and specific assets on opportunism, and rarely has it explored the relation between turbulent environment and specific assets. Such a relation undoubtedly exists, and its consequences alter the effect of the above factors on the opportunist attitudes displayed by the parties to the transaction, and they also legitimise investing in specific assets.

As evidenced above, specific assets increase the level of transaction risk, and consequently also the risk of opportunist attitudes emerging. However, it should also be noted that investments in specific assets offer many benefits for the parties to a transaction, including the knowledge to be acquired, information exchange systems, efficient collaboration and communication, and improved speed of response. All things considered, such investments can reduce both production costs and transaction costs. An example can be employee training 
on contacts with the counterparties, making it significantly easier to develop efficient collaboration. Therefore, specific assets can contribute to a reduction of coordination costs which constitute a component of transaction costs.

Given the fact that acquiring up-to-date and accurate information on market changes, technological developments, and the conduct of parties to the transaction is difficult in turbulent environment, specific assets are prerequisite to successfully managing uncertainty and reducing coordination costs (Krishnan et al., 2006; Lee et al., 2009). As mentioned, turbulent environment generates large amounts of information which must be processed to achieve a specific goal. For instance, demand and supply uncertainty generates enormous amounts of information concerning demand and supply over a short span of time. Uncertainty of technology generates information about the latest technologies. In order to handle such a situation, the counterparties should improve their information processing capabilities. Investing in specific assets (e.g. in IT systems, personnel training, etc.) significantly improves the capacity to solve the problems connected with adapting to, and assessing such uncertainty. Integrated information systems enable the parties to quickly process the changing information on demand and supply, as well as to analyse the impact of turbulent environment on their operations.

\section{CONCLUSION}

The above considerations confirm the general hypothesis which was initially formulated about the influence of specific assets and turbulent environment on the opportunistic attitudes presented by participants of a transaction. Although a large group of authors share this opinion, a wideranging empirical research is needed to decide on the complete verification of the hypothesis. Most authors tend to agree that opportunism is a source of transaction costs, yet they differ in their views in terms of how opportunism actually functions as the only source of these costs. However, this does not change the fact that limiting opportunism leads to the reduction of transaction costs, and consequently also to efficiency improvement. Considering all this, the need for further studies on the problem of opportunism and the ways to limit it appears substantiated. In two out of all the sources of opportunism analysed in this paper, the impact of specific assets was studied most thoroughly to date, but considering the complexity of this impact, further research is clearly recommendable even in this sphere. The limited scope of past research on the impact of turbulent environment on the opportunist attitudes among the parties to the transaction makes it impossible to explicitly determine the magnitude of this impact. 
Having broken down transaction costs into coordination costs and transaction risk, one can claim that turbulent environment and specific assets affect these costs in a different manner. Turbulent environment causes high coordination costs and high transaction risk, which is a clear evidence of its impact on the increase of transaction costs. The case of specific assets is more complex, since they indeed increase transaction risk and pose a threat of opportunism. However, they may prove useful when attempting to reduce coordination costs, making it possible to respond adequately to uncertainty triggered by turbulent environment.

\section{REFERENCES}

Bhattacharya, A., Singh, P. J., Nand, A. A., Antecedents of buyer opportunistic behavior in outsourcing relationships, International Journal of Production Economy, Vol. 166, 2015.

Carson, S. J., Madhok, A., Wu, T., Uncertainty, opportunism, and governance: the effects of volatility and ambiguity on formal and relational contracting, Academy of Management Journal, Vol. 49, No. 5, 2006.

Chakravarti, A., Imperfect information and Opportunism, Journal of Economic Issues, Vol. 51, No. 4, 2017.

Clemons, E. K., Reddi, S. P., Roe, M. C., The impact of information technology on the organization of economic activity: "the move to the middle" hypothesis, Journal of Management Information Systems, Vol. 10, No. 2, 1993.

Ganesan, S., Brown, S. P., Mariadoss, B. J., Ho, H., Buffering and amplifying effects of relationship commitment in business-to business relationships, Journal of Marketing Research, Vol. 47, 2010.

Grover, V., Malhotra, M. K., Transaction cost framework in operations and supply chain management research theory and measurement, Journal of Operations Management, Vol. 30, No. 1-2, 2003.

Handley, S. M., Benton, W. C., The influence of exchange hazards and power on opportunism in outsourcing relationship, Journal of Operations Management, vol. 30, 2012.

Hawkins, T. G., Wittmann, C. M., Beyerlein, M. M., Antecedents and consequences of opportunism in buyer-supplier relations: research synthesis and new frontiers, Industrial Marketing Management, Vol. 37, No. 8, 2008.

Hodgson, G. M., Opportunism is not the only reason why firms exist: why an explanatory emphasis on opportunism may misled management strategy, Industrial and Corporate Change, Vol. 13, No. 2, 2004.

Huo, B., Ye, Y., Zhao, X., Wej, J., Hua, Z., Environmental uncertainty, specific assets, and opportunism In 3PL relationships: A transaction cost economics perspective, International Journal of Production Economics, Vol. 203(C), 2018.

Jap, S. D., Robertson, D. C., Rindfleisch, A., Hamilton, R., Low stakes-opportunism, Journal of Marketing Research, Vol. 50, 2013.

Jensen, M. C., Meckling, W. H., The Nature of Man, Journal of Applied Corporate Finance, Vol. 7, No. 2, 1994. 
Krishnan, R., Martin, X., Noorderhaven, N. G., When does trust matter to alliance performance?, Academy of Management Journal, Vol. 49, No. 5, 2006.

Lee, P. K. C., Yeung, A. C. L., Cheng, T. C. L., Supplier alliances and environmental uncertainty: an empirical study, International Journal of Production Economics., Vol. 120, No. 1, 2009.

Lissowska, M., Instytucje gospodarki rynkowej w Polsce [Institutions for Market Economy. The Case of Poland]. Wydawnictwo C. H. Beck, Warszawa 2008.

Marcinkowska, E., Wplyw teorii kosztów transakcyjnych i teorii zasobowej na proces decyzyjny outsourcingu [Effect of the transaction cost theory and resource-based theory on the decision making process in outsourcing], Studia Ekonomiczne. Zeszyty Naukowe Uniwersytetu Ekonomicznego w Katowicach, No. 341, 2017.

Mysen, T., Svensson, G., Payan, J., The key role of opportunism in a business relationship, Marketing Intelligence \& Planning, Vol. 29, No. 4, 2011.

Noorderhaven, N. G., Opportunism and Trust in Transaction Cost Economics [in:] Groenewefen, J. (ed.), Transaction Cost Economics and Beyond. Kluwer Academic Publisher 1996.

Noordewier, T. G., John, G., Nevin, J. R., Performance outcomes of purchasing arrangements in an industrial buyer-vender relationship, Journal of Marketing, Vol. 54, No. 4, 1990.

Pfeffer, J., Salancik, G. R., The External Control of Organizations: A Resource Dependence Perspective. Stanford University Press, Stanford, CA, 2003.

Piórkowska, K., Strategia behawioralna wyznacznikiem sukcesu organizacji? [Behavioural strategy as an indicator of an organisation's success], Zarządzanie i Finanse, Vol. 2, No. 4, 2013.

Schilling, M. A., Steensma, H. K., Disentangling the theories of firm boundaries: a path model and empirical tests, Organization Science, Vol. 13, No. 4, 2002.

Verbeke, A., Greidanus, N. S., The end of the opportunism vs trust debate: Bounded reliability as a new envelope concept in research on MNE governance, Journal of International Business Studies, Vol. 40, 2009.

Wang, Q., Li, J. J., Ross Jr, W. T., Craighead, Ch. W., The interplay of drivers and deterrents of opportunism in buyer-supplier relationships, Journal of the Academy Marketing Science, Vol. 4, 2013.

Wathne, K. H., Hejde, J. B., Opportunism in interfirm relationships: forms, outcomes, and solutions, Journal of Marketing, Vol. 64, 2000.

Wilkin J., Instytucjonalne i kulturowe podstawy gospodarowania. Humanistyczna perspektywa ekonomii [Institutional and cultural basis of the economy. Humanistic perspective of economics]. Wydawnictwo Naukowe SCHOLAR, Warszawa 2016.

Williamson, O. E., Markets and Hierarchies: Analysis and anti-trust implications. Free Press, New York 1975.

Williamson, O. E., Ekonomiczne instytucje kapitalizmu. Firmy rynki relacje kontraktowe [The Economic Institutions of Capitalism: Firms, Markets, Relational Contracting]. Wydawnictwo Naukowe PWN, Warszawa 1998.

Williamson, O. E., Transaction Cost Economics [in:] Menard, C., Shirley, M. M. (eds.), Handbook of New Institutional Economics. Springer, New York 2005.

Williamson, O. E., Transaction Costs Economics: The Governance of Contractual Relations, Journal of Law and Economics, No. 22(2), 1979.

Received: January 2020, revised: October 2020 